\title{
MicroRNA-141 ameliorates alcoholic hepatitis-induced intestinal injury and intestinal endotoxemia partially via a TLR4-dependent mechanism
}

\author{
WEI-HE QIAN $^{1 *}$, YUAN-YUAN LIU ${ }^{2,3^{*}}$, XIANG LI $^{1}$ and YAN PAN ${ }^{4}$ \\ ${ }^{1}$ Department of Clinical Laboratory, The Affiliated Huai'an Hospital of Xuzhou Medical University, Huai'an, Jiangsu 223302; \\ ${ }^{2}$ Department of Endocrinology, The Affiliated Huai'an No. 1 People's Hospital of Nanjing Medical University, \\ Huai'an, Jiangsu 223300; ${ }^{3}$ Department of Endocrinology, The First Affiliated Hospital of Soochow University, Suzhou, \\ Jiangsu 215006; ${ }^{4}$ Department of Clinical Laboratory, Lianshui County People's Hospital, Huai'an, Jiangsu 223400, P.R. China
}

Received September 14, 2018; Accepted April 23, 2019

DOI: $10.3892 /$ ijmm.2019.4221

\begin{abstract}
Alcoholic hepatitis (AH) is a fatal inflammatory syndrome with no effective treatments. Intestinal injury and intestinal endotoxemia (IETM) contribute greatly in the development of AH. MicroRNAs (miRNAs/miRs) have been reported to affect intestinal injury. The present study aims to investigate the role of miR-141 in intestinal injury and IETM of AH. An AH model was successfully established in mice and they were the injected with a series of miR-141 mimic, miR-141 inhibitor or toll like receptor 4 monoclonal antibody (TLR4mAb; an inhibitor of the Toll-like receptor TLR pathway). After that, the intestinal tissues and intestinal epithelial cells were isolated from differently treated AH mice. The expression of miR-141 and TLR pathway-associated genes and the levels of inflammatory factors were determined. Furthermore, a target prediction program and a luciferase reporter assay were employed to examine whether miR-141 targets TLR4. Finally, MTT and transwell assays were carried out to detect cell viability and cell permeability. Intestinal tissues from $\mathrm{AH}$ mice treated with miR-141 mimic or TLR $4 \mathrm{mAb}$ exhibited lower levels of inflammatory factors and reduced expression of the TLR pathway-associated genes, suggesting a decreased inflammatory response as well as inactivation of the TLR pathway by miR-141. The luciferase reporter assay suggested that miR-141 negatively regulated TLR4. Intestinal epithelial cells treated with miR-141 mimic or TLR4mAb demonstrated enhanced viability and reduced permeability. Opposite results
\end{abstract}

Correspondence to: Dr Yan Pan, Department of Clinical Laboratory, Lianshui County People's Hospital, 6 East of Hongri Avenue, Huai'an, Jiangsu 223400, P.R. China

E-mail: dr_pan_yan@163.com

${ }^{*}$ Contributed equally

Key words: microRNA-141, Toll-like receptor, alcoholic hepatitis, intestinal injury, intestinal endotoxemia were observed in AH mice treated with a miR-141 inhibitor. Collectively, the results of the present study demonstrated that miR-141 could ameliorate intestinal injury and repress the progression of IETM through targeting TLR4 and inhibiting the TLR pathway.

\section{Introduction}

Alcoholic hepatitis $(\mathrm{AH})$ is an acute inflammatory syndrome that can result in high morbidity and mortality (1). $\mathrm{AH}$, as a severe liver injury, is associated with both acute hepatocellular dysfunction and chronic liver failure that can finally lead to death (2). Present evidence demonstrated that AH results from the complicated interaction between alcohol metabolism, inflammation and innate immunity (3). People with chronic or active alcohol abuse have the potential to suffer from $\mathrm{AH}$ and there will be $30-40 \%$ mortality after a month in certain severe cases (4). However, corticosteroids or pentoxifylline which are the current drug treatment options only result in $\sim 50 \%$ survival (5). Alcoholic liver disease (ALD) is a common liver disease worldwide and acute $\mathrm{AH}$ is characterized by the fact that macrophage inflammatory cytokines disproportionately respond to bacterial lipopolysaccharide (6). Alcohol also has an influence on the intestine, contributing to the increase of intestinal permeability and the change of bacterial microflora (7). The human intestine embodies a large number of microbes promoting metabolism and digestion and the alterations of intestinal microbiota is associated with liver diseases (8). In addition, previous evidence suggests that endotoxemia has a close association with ALD in that circulating endotoxins stem from intestinal microflora and gut barrier dysfunction can cause increased intestinal permeability (9).

At present, it is reported that microRNAs (miRs) serve an important role in ALD (10). Certain miRs (like miR-223, miR-155 and miR-125) exhibited an abnormal miRNA profile that was influenced by alcohol and is associated with the pathogenesis of ALD (11). miR-182 serves a crucial role in disease severity and liver injury of $\mathrm{AH}$ and is a potential therapeutic target and biomarker of AH (12). A previous study revealed that miR-122, rich in hepatocytes, is associated 
with acute alcohol-induced liver injury and miR-155 regulated inflammation in ALD and targeted Toll-like receptor (TLR) signaling concerning pro-and anti-inflammatory cytokines (13). As previously reported, the TLR signaling pathway serves a role in a number of diseases including neuro-inflammatory disorders, alcohol abuse and chronic inflammation (14). miR-141 was identified to be involved in the process of epithelial-mesenchymal transition (15), which was decreased in hepatocellular carcinoma (HCC) and overexpression of miR-141 could inhibit the growth and metastasis of HCC cells (16). In addition, Huang et al (17) have identified the crucial antagonistic roles of miR-141-3p in the modulation of invasive potential in HCC cells. Furthermore, miR-141 seems to serve a role in the bowel inflammation of individuals with active ulcerative colitis via downregulation of C-X-C motif chemokine 5 (CXCL5) expression (18). However, there are few studies on the role of miR-141 in AH. Therefore, the present study would like to investigate the role of miR-141 in intestinal injury and intestinal endotoxemia (IETM) of AH and its interaction with partially TLR4-mediated signaling pathway. The present study aimed to test the hypothesis that miR-141 could inhibit the activation of the TLR pathway by targeting TLR4, therefore alleviating the intestinal injury of $\mathrm{AH}$ and inhibit the occurrence of IETM.

\section{Materials and methods}

Ethics statement. All involved animal experiments were in line with the principles of the approval of the clinical ethical committee of the Affiliated Huai'an Hospital of Xuzhou Medical University (Huai'an, China). Significant efforts were made in order to minimize the number of animals used as well as their respective suffering.

Study subjects. A total of 45 C57BL/6 male mice (aged 6 weeks; weighing 18-22 g) were provided by the experimental animal center of Peking University Health Science Center (Beijing, China) and randomly assigned into normal group (10 mice) and AH group (35 mice). The mice in the normal group were fed with Lieber-Decarli alcohol-free liquid while mice in the AH group were fed with Lieber-Decarli alcohol. The two types of liquid contained an equal calorie content. The mice were kept in a specific pathogen-free animal laboratory with $40-70 \%$ humidity, $24 \pm 2^{\circ} \mathrm{C}$ and day and night cycle of artificial lighting (day time: 08:00 a.m.-08:00 p.m.). The criteria for validated AH model were as follows (19): Mice exhibited unkempt and lackluster hair, decreased activity, slow reaction and slow weight gain. After 6 weeks of alcohol feeding, five mice were euthanized in the normal group and the AH group, respectively. The pathological alterations of liver tissues were observed by hematoxylin and eosin (H\&E) staining to determine whether the model was successfully constructed. The remaining mice were randomly selected and fasted for $12 \mathrm{~h}$. Mice were anaesthetized by intraperitoneal injection with $2 \%$ sodium pentobarbital $(50 \mathrm{mg} / \mathrm{kg})$ and then the $1 \mathrm{ml}$ cardiac blood was collected, mixed in vacuum tube (Becton, Dickinson and Company), centrifuged at $600 \mathrm{x} \mathrm{g}$ for $5 \mathrm{~min}$ at $4^{\circ} \mathrm{C}$ and preserved at $-20^{\circ} \mathrm{C}$. Intestinal tissues were collected at $3 \mathrm{~cm}$ from the anus, a part of which were kept in liquid nitrogen and the other part were fixed in $10 \%$ neutral formalin for $24 \mathrm{~h}$ at room temperature, which were then dehydrated by gradient alcohol $(100,95,80$ and $70 \%$, each for $2 \mathrm{~min}$ ), immersed in a wax box at $60^{\circ} \mathrm{C}$ for $12 \mathrm{~h}$ and embedded for $2 \mathrm{~h}$ for further use.

Animal grouping. According to the mmu-miR-141 sequence at www.miRbase.org website and the RNA sequence design principle, the miR-141 irrelevant sequences (5'-UAGAAAUGG AGUAGCAAUGAU-3'), miR-141 mimic sequence (5'-UAG AAAUGGUCUAGUCACAAU-3') and miR-141 inhibitor sequence (5'-AUUGUGACUAGACCAUUUCUA-3') were designed and synthesized by Shanghai Genechem Co., Ltd. The amplified target fragments and the linearized expression plasmid pcDNA3.1(-) (Invitrogen; Thermo Fisher Scientific, Inc.) following enzyme digestion with BamHI and HindIII (Invitrogen; Thermo Fisher Scientific, Inc.) were reacted overnight at $16^{\circ} \mathrm{C}$ by T4 DNA ligase. Next, the products were incubated with DH5 $\alpha$ competent cells (CB101; Tiangen Biochemical Technology Co., Ltd.) on ice for $30 \mathrm{~min}$, at $42^{\circ} \mathrm{C}$ for $90 \mathrm{sec}$ and again on ice for $5 \mathrm{~min}$. Next, the mixture was supplemented with $800 \mu 1$ lysogeny broth (LB) liquid medium without antibiotics and incubated at $37^{\circ} \mathrm{C}$ for $45 \mathrm{~min}$, resuspended in $200 \mu \mathrm{l}$ LB liquid medium without antibiotics, and then placed on a MAC culture plate (cat. no. HB8458; Hope Biotechnology Co., Ltd.) containing antibiotics (ampicillin) for $12-16 \mathrm{~h}$ at $37^{\circ} \mathrm{C}$. The next day, the positive clones were selected and sequenced. The cells that failed to be transformed could not grow on the MAC culture plate; cells without recombinant plasmid transformation appeared red on the MAC culture plate, and cells with recombinant plasmid transformation appeared white on the MAC culture plate. The white colonies were the positive clones that were selected.

C57BL/6 mice were further classified into 7 groups: Normal group (normal mice without any treatment), blank group (AH mice without treatment), negative control group (NC group, AH mice injected with blank plasmid), miR-141 mimic group (AH mice injected with miR-141 mimics), miR-141 inhibitor group (AH mice injected with miR-141 inhibitors), TLR4mAb group (AH mice injected with TLR pathway inhibitor TLR4mAb), miR-141 inhibitor + TLR4mAb group (AH mice co-injected with miR-141 inhibitors and TLR $4 m A b$ ), with 5 mice in each group. Mice were anesthetized with $2 \%$ sodium pentobarbital, fixed with their limbs supine on the operating table and injected with plasmids $(50 \mathrm{nM})$ via the tail vein. A total of 4 weeks following treatment, all mice were fasted for $12 \mathrm{~h}$. The cardiac blood was collected, mixed in vacuum tube (Becton, Dickinson and Company), centrifuged at $604 \mathrm{xg}$ for $5 \mathrm{~min}$ at $4^{\circ} \mathrm{C}$ and preserved at $-20^{\circ} \mathrm{C}$. Intestinal tissues were collected at $3 \mathrm{~cm}$ from the anus, washed by phosphate buffer saline (PBS), fixed by $4 \%$ formalin at room temperature for $24 \mathrm{~h}$, embedded by paraffin and then sliced $(3-5 \mu \mathrm{m})$ for further use.

Dual-luciferase reporter gene assay. The possible target genes of miR-141 were predicted at microRNA.org and the sequences of targeting sites were obtained. The 3'untranslated region (UTR) of TLR4 was amplified and cloned to pmirGLO (E1330; Promega Corp.) Luciferase vector, named pTLR4-wild type (Wt). The binding sites of miR141 on TLR4 were predicted using an online database (microRNA.org) and 
mutated. The mutant form of 3'UTR of TLR4 was also cloned into pmirGLO vector to construct pTLR4-mutant (Mut). The pRL-TK vector expressing Renilla luciferase (cat. no. E2241; Promega Corp.) was regarded as an internal reference. Using the Lipofectamine ${ }^{\circledR} 2000$ transfection reagent (Invitrogen; Thermo Fisher Scientific, Inc.), the miR-141 mimic or miR-141 NC were respectively co-transfected with pTLR4-Wt or pTLR4-Mut into 293T cells (CRL-1415; American Type Culture Collection). Following $36 \mathrm{~h}$ of transfection, the fluorescence detector (Glomax20/20; Promega Corp.) was used to detect luciferase activity. The ratio of firefly luciferase to Renilla luciferase was used to calculate the relative luciferase activity.

$H \& E$ staining. A total of 5 paraffin-embedded intestinal tissues were selected from each group and cut into 5- $\mu \mathrm{m}$ serial sections. After incubating for $1 \mathrm{~h}$ at $60^{\circ} \mathrm{C}$, the sections were dewaxed with xylene I and II for $5 \mathrm{~min}$. The sections were then dehydrated by gradient alcohol (alcohol concentration of 70 , 80,95 and $100 \%$, each for $2 \mathrm{~min}$ ) and washed by distilled water 2 times for $5 \mathrm{~min}$ each time. Following hydration, the sections were stained with routine H\&E (Beijing Solarbio Technology Co., Ltd.) at room temperature for $3 \mathrm{~min}$, washed by running water for $5 \mathrm{~min}$, dehydrated by 70 and $80 \%$ ethanol $(5 \mathrm{~min}$ each), cleared by xylene I and II (5 min each) and sealed with neutral balsam. Lastly, a transmitted polarizing microscope (XP-330; Shanghai Bing Yu Optical Instrument Co., Ltd.) was used to observe the pathological alterations of sections and then the sections were scored according to the scoring standard by Geboes et al (20) (Table I). A total of 10 sections were selected from each group and the average value was taken.

Activities of serum endotoxin, D lactic acid, diamineoxidase (DAO) and alanine aminotransferase (ALT). The activities of serum endotoxin, D lactic acid and DAO were measured from the serum of 5 mice in each group. The content of endotoxin was determined by modified substrate azo dye method using kit purchased from Shanghai Biochemical Institute. Colorimetric detection was conducted using the 721 spectrophotometer (Shanghai Precision and Scientific Instrument Corporation). D lactic acid was detected by modified enzyme spectrophotometric method. D lactic acid standard solution (69806) and lactate dehydrogenase (D-LDH; 61309) were purchased from Sigma-Aldrich; Merck KGaA. DAO was determined by o-dianisidine reagent method. Cadaverine dihydrochloride (cat. no. D9143), o-dianisidine (cat. no. 540765), DAO standard solution (cat. no. 77332) and horseradish peroxidase (cat. no. MAK037) were purchased from Sigma-Aldrich; Merck KGaA. ALT in serum was determined using 96-well spectrophotometry using the ALT kit (cat. no. SEA207Mu; Shanghai Chao Yan Biotechnology Co., Ltd.). The operation was performed according to the kit protocol and the experiment was repeated 3 times.

Immunohistochemistry. A total of 5 paraffin-embedded mice intestinal tissues of each group were randomly selected and the sections $(3-4 \mu \mathrm{m})$ were prepared. The sections were put into $3 \% \mathrm{H}_{2} \mathrm{O}_{2}$, dewaxed by xylene I and II (10 min each), dehydrated by gradient alcohol (alcohol concentration of 70, 80, 95 and $100 \%$ for 2 min each), and washed by distilled water 2 times, 5 min each (placed in a shaker). The sections were immersed
Table I. Pathological judgement criteria for intestinal injury.

\begin{tabular}{lcccc}
\hline Histological appearance & No & Light & Moderate & Severe \\
\hline Mucosal injury & 0 & 1 & 2 & 3 \\
Crypt destruction & 0 & 1 & 2 & 3 \\
Mucosal bleeding & 0 & 1 & 2 & 3 \\
Interstitial injury & 0 & 1 & 2 & 3 \\
Inflammatory cell infiltration & 0 & 1 & 2 & 3
\end{tabular}

with $3 \% \mathrm{H}_{2} \mathrm{O}_{2}$ for $10 \mathrm{~min}$ and washed by distilled water. After the antigen was repaired at high pressure for $90 \mathrm{sec}$, the sections were cooled to room temperature and washed with PBS. The sections were blocked with $5 \%$ bovine serum albumin (cat. no. A1933; Sigma-Aldrich; Merck KGaA) at $37^{\circ} \mathrm{C}$ for $30 \mathrm{~min}$ and incubated at $4^{\circ} \mathrm{C}$ overnight with the monoclonal antibody rabbit anti-mouse TLR4 (cat. no. ab13556; Abcam) or $\mathrm{CD}_{14}$ (cat. no. ab78333; Abcam; 1:100). The sections were then washed and incubated with biotinylated goat anti-rabbit immunoglobulin $\mathrm{G}$, horse radish peroxidase (HRP) secondary antibody (cat. no. SE134; 1:1,000, Beijing Solarbio Science \& Technology Co., Ltd.) for $30 \mathrm{~min}$ at $37^{\circ} \mathrm{C}$. After that, the sections were treated with hematoxylin (cat. no. C0105; Beyotime Institute of Biotechnology) at room temperature to counterstain the nucleus for $30 \mathrm{sec}$, developed by diaminobenzidine (DAB; cat. no. P0202; Beyotime Institute of Biotechnology) at room temperature for 3-10 $\mathrm{min}$, dehydrated by hydrochloric acid ethanol, sealed with neutral balsam and observed and images were captured under the light microscope. A total of 5 fields under high-power lens were randomly selected. The judgment standards of immunohistochemistry were as follows (21): The brownish yellow signal mainly located in the cytoplasm or cell membrane was considered to indicate positively stained cells. The percentage of cells with positive expression of TLR4 and $\mathrm{CD}_{14}$ in the total number of cells was calculated. The experiment was repeated 3 times.

ELISA. The serum was taken from 5 mice of each group. The tumor necrosis factor- $\alpha$ (TNF- $\alpha$; cat. no. 69-25328), interleukin-6 (IL-6; cat. no. 69-40133) and IL $1 \beta$ (cat. no. 69-30375) ELISA kits were purchased form Wuhan Moshake Biotechnology Co., Ltd. Serum samples $(100 \mu \mathrm{l})$ were added into the reaction wells and incubated at $37^{\circ} \mathrm{C}$ for $90 \mathrm{~min}$. The wells were then incubated with $100 \mu \mathrm{l}$ freshly-prepared biotinylated antibody at $37^{\circ} \mathrm{C}$ for $60 \mathrm{~min}$. After washing, the wells were incubated with $100 \mu \mathrm{l}$ freshly-prepared enzyme bound reactant at $37^{\circ} \mathrm{C}$ for $30 \mathrm{~min}$ avoiding exposure to light. The substrate $(100 \mu \mathrm{l})$ was then added to the samples and incubated at $37^{\circ} \mathrm{C}$ for $15 \mathrm{~min}$ avoiding exposure to light. After that, the stop solution was added immediately to terminate the reaction. Within $3 \mathrm{~min}$, the OD value was measured at $450 \mathrm{~nm}$ wavelength by Microplate Reader (Multiskan GO; Thermo Fisher Scientific, Inc.). The experiment was repeated 3 times.

Reverse transcription-quantitative polymerase chain reaction $(R T-q P C R)$. The intestinal tissues preserved in liquid nitrogen from 5 mice in each group were randomly selected, ground and $1 \mathrm{ml}$ TRIzol reagent was added (Invitrogen; Thermo Fisher 
Table II. Primer sequence for reverse transcription quantitative polymerase chain reaction.

\begin{tabular}{|c|c|}
\hline Gene & Sequence \\
\hline \multirow[t]{2}{*}{ miR-141 } & Forward: 5'-CCGGGTAACACTGTCTGGTAAAG-3' \\
\hline & Reverse: 5'-GTGCAGGGTCCGAGGT-3' \\
\hline \multirow[t]{2}{*}{ U6 } & Forward: 5'-GCTTCGGCAGCACATATACTAAAAT-3' \\
\hline & Reverse: 5'-CGCTTCACGAATTTGCGTGTCAT-3' \\
\hline \multirow[t]{2}{*}{ TLR4 } & Forward: 5'-GCAATGTCTCTGGCAGGTGTA-3' \\
\hline & Reverse: 5'-CAAGGGATAAGAACGCTGAGA-3' \\
\hline \multirow[t]{2}{*}{$\mathrm{CD}_{14}$} & Forward: 5'-TTGCCGAGGTTCAAGATC-3' \\
\hline & Reverse: 5'-TGTGGACACGGAAGCAGA-3' \\
\hline \multirow[t]{2}{*}{ NF-кBp65 } & Forward: 5'-TGCGAATGGAGCGACAGG-3' \\
\hline & Reverse: 5'-AGGCCAAATGAAAGGAGTGG-3' \\
\hline \multirow[t]{2}{*}{ MyD88 } & Forward: 5'-GGCATTTCACTGCTTGATGT-3' \\
\hline & Reverse: 5'-TGACATTCCCATGAAACCTC-3' \\
\hline \multirow[t]{2}{*}{ TRIF } & Forward: 5'-TCAGAGAGTCCATCATTCGG-3' \\
\hline & Reverse: 5'-TACACGCCCACTCTTCTGAG-3' \\
\hline \multirow[t]{2}{*}{ PCNA } & Forward: 5'-AGGGCTGAAGATAATGCTGATA-3' \\
\hline & Reverse: 5'-CTCATTCATCTCTATGGTCACAG-3' \\
\hline \multirow[t]{2}{*}{ GAPDH } & Forward: 5'-GCAAGTTCAACGGCACAG-3' \\
\hline & Reverse: 5'-CGCCAGTAGACTCCACGAC-3' \\
\hline
\end{tabular}

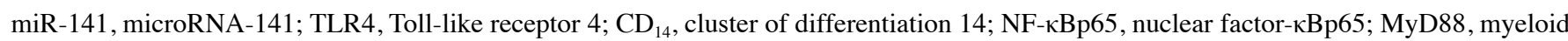
differentiation factor 88 ; TRIF, TIR-domain-containing adaptor inducing interferon- $\beta$; PCNA, proliferating cell nuclear antigen.

Scientific, Inc.) to extract total RNA according to the instructions (total RNA extraction from cells was also conducted according to this method). The purity and concentration of RNA were detected by ultraviolet spectrophotometry (cat. no. UV1901; Shanghai AuCybest Technology Instrument Co., Ltd.). The RNAs were reverse transcribed into cDNAs (50 ng/ $\mu$ l) by PrimeScript ${ }^{\text {TM }}$ RT reagent kit (cat. no. RR047A; Beijing Think-Far Technology Co., Ltd.). The reaction condition was as follows: Reverse transcription reaction at $37^{\circ} \mathrm{C}$ 3 times, each for $15 \mathrm{~min}$, reverse transcriptase inactivation reaction at $85^{\circ} \mathrm{C}$ for $5 \mathrm{sec}$ and cryopreservation at $-80^{\circ} \mathrm{C}$ for later use. The primers for RT-qPCR (LightCycler FastStart DNA Master PLUS SYBR Green I kit; Roche Diagnostics) were designed using Premier 5.0 software (Premier Biosoft International) and synthesized by Beijing Qingke Xinye Biological Technology Co., Ltd. (22) (Table II). The reaction was conducted in an ABI 7900HT RT-qPCR instrument (ABI 7900, Shanghai Pudi Biological Technology Co. Ltd.) in the light of two-step method. U6 was used as the internal reference of miR-141 and GAPDH was regarded as the internal reference for other genes. The reaction conditions were as follows: Pre-denaturation at $95^{\circ} \mathrm{C}$ for $30 \mathrm{sec}, 40$ cycles of denaturation at $95^{\circ} \mathrm{C}$ for $5 \mathrm{sec}$, annealing at $58^{\circ} \mathrm{C}$ for $30 \mathrm{sec}$, followed by extension at $72^{\circ} \mathrm{C}$ for $15 \mathrm{sec}$. The $2^{-\Delta \Delta \mathrm{Cq}}$ method (23) was applied to calculate the relative mRNA expression of miR-141, TLR4, $\mathrm{CD}_{14}$, NF- $\kappa$ Bp65, myeloid differentiation primary response 88 (MyD88), TIR-domain-containing adapter-inducing interferon- $\beta$ (TRIF) and proliferating cell nuclear antigen (PCNA) in intestinal tissues. A total of three duplicated wells were set for each sample. The experiment was repeated 3 times.
Western blot analysis. The liquid nitrogen preserved intestinal tissues were randomly selected from 5 mice in each group. The tissues were ground, washed with PBS 3 times, lysed with $100 \mu \mathrm{l}$ tissue RIPA lysis buffer $(2 \mu \mathrm{g} / \mu \mathrm{l}$; cat. no. 20101ES60; Yeasen Biotechnology Co. Ltd.) on ice for $5 \mathrm{~min}$ and centrifuged at $9,668 \times \mathrm{g}$ for $20 \mathrm{~min}$ at $4^{\circ} \mathrm{C}$. The concentration of total protein was detected using bicinchoninic acid kit (P0012-1; Beyotime Institute of Biotechnology). Cells in logarithmic growth phase were collected, centrifuged at $604 \mathrm{x} \mathrm{g}$ for $20 \mathrm{~min}$ at $4^{\circ} \mathrm{C}$ with supernatant discarded and lysed with $100 \mu$ lysate (containing $20 \mathrm{mM}$ Tris, $150 \mathrm{mM} \mathrm{NaCl}$ and $1 \%$ Triton) and $1 \mu \mathrm{l}$ phosphatase inhibitor (1111111; Roche Diagnostics) for $30 \mathrm{~min}$ on ice, and then centrifuged at 9,668 x $\mathrm{g}$ for $10 \mathrm{~min}$ at $4^{\circ} \mathrm{C}$. A total of $50 \mu \mathrm{g}$ proteins were dissolved in 2X SDS loading buffer, boiled at $100^{\circ} \mathrm{C}$ for $5 \mathrm{~min}$, separated by $10 \%$ SDS-PAGE gel and transferred to a polyvinylidene fluoride (PVDF) membrane. The PVDF membrane was blocked in $5 \%$ skimmed milk powder at room temperature for $1 \mathrm{~h}$ and washed with PBS for 2 min. The membrane was incubated with rabbit anti-mouse primary antibodies (TLR4; diluted at 1:500; cat. no. ab13556; $\mathrm{CD}_{14}, 1: 100$; cat. no. ab18322; NF-кBp65; 1:2,000; cat. no. ab86299; MyD88; 1:1,000; cat. no. ab2064; TRIF; 1:500; cat. no. ab13810; PCNA; 1:1,000; cat. no. ab92552; GAPDH, 1:1,000; cat. no. ab8245) at $4^{\circ} \mathrm{C}$ overnight. After washing 3 times with Tris-Buffered Saline and $0.05 \%$ Tween-20 (TBST), the membrane was incubated with HRP-labeled secondary antibody goat anti-rabbit (1:5,000; cat. no. ab97051; Abcam) for $1 \mathrm{~h}$. Then, the membrane was rinsed with TBST 3 times for $5 \mathrm{~min}$ each and developed using an ECL fluorescent detection kit (cat. no. C10001; Pierce; Thermo Fisher Scientific, Inc.), exposed by X-ray and the image was 


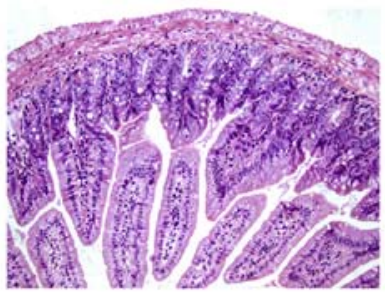

Normal

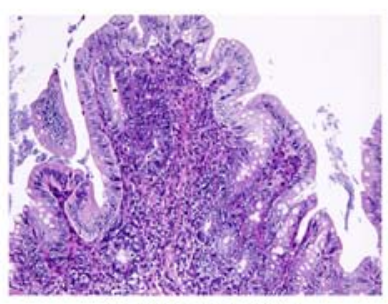

miR-141 inhibitor

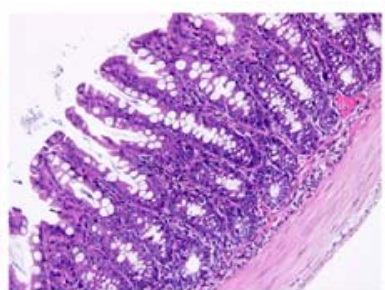

Blank

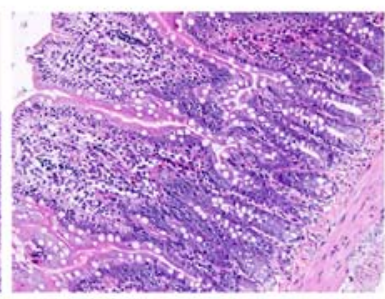

TLR4mAb

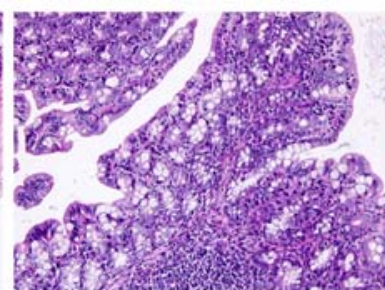

NC

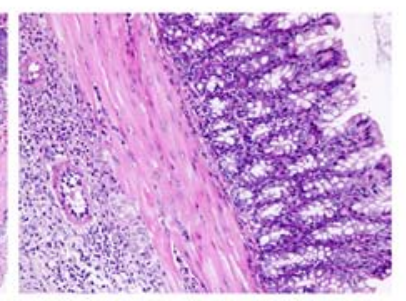

miR-141 inhibitor+TLR4mAb

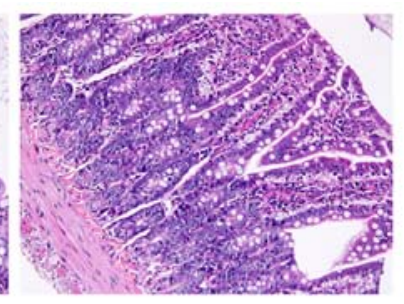

miR-141 mimic

Figure 1. miR-141 ameliorates alcoholic hepatitis-induced pathological alterations in the intestinal tissues, observed by hematoxylin and eosin staining (magnification, x200). miR-141, microRNA-141; NC, negative control; TLR4mAb, Toll-like receptor 4 monoclonal antibodies.

captured. Gel imaging analysis system (GelDoc XR+, Bio-Rad Laboratories Co., Ltd.) was applied to analyze the OD of color band. The relative content of proteins was expressed as the ratio of average $\mathrm{OD}$ of the sample to that of the corresponding internal reference according to the statistical analysis chart that was calculated. The experiment was repeated 3 times.

Cell treatment. The mice intestinal tissues in each group were washed several times with PBS containing antibiotics (1\% penicillin and streptomycin) under aseptic conditions. The intestinal wall was cut into pieces $<1 \mathrm{~mm}^{3}$, transferred to $50 \mathrm{ml}$ centrifugal tubes, washed in DMEM (Invitrogen; Thermo Fisher Scientific, Inc.) without serum, mixed repeatedly with a pipette and centrifuged at $67 \mathrm{x} \mathrm{g}$ for $3 \mathrm{~min}$ at $4^{\circ} \mathrm{C}$. The above steps were repeated until the supernatant was clear. The tissue blocks were suspended by DMEM containing 5\% fetal bovine serum (FBS; Invitrogen; Thermo Fisher Scientific, Inc.) and cultured in a culture plate or a culture flask for several days. Next, cells were washed using PBS, detached by $0.05 \%$ trypsin-ethylenediaminetetraacetic acid (EDTA) for 1-2 min, treated again with $0.05 \%$ trypsin-EDTA for 2-3 min, mixed with $0.05 \%$ FBS-DMEM and cultured.

MTT Assay. The cell suspension was inoculated onto a 96-well plate with a density of $1 \times 10^{4}$ cells per well $(200 \mu \mathrm{l}$ in each well). The culture plate was placed in an incubator with $5 \% \mathrm{CO}_{2}$ at $37^{\circ} \mathrm{C}$ with the culture medium changed every other day. When the cells adhered to the wall, cells in each well were incubated with $10 \mu 15 \mathrm{mg} / \mathrm{ml}$ MTT solution (Sigma-Aldrich; Merck $\mathrm{KGaA}$ ) for $4 \mathrm{~h}$. Then $150 \mu \mathrm{l}$ dimethylsulfoxide was added to the cells in each well were added and agitated for 10 min to fully dissolve. The OD value of each well was determined at $490 \mathrm{~nm}$ wavelength by an automatic enzyme reading meter (Bio-Rad Laboratories, Inc.). The experiment was repeated 3 times.

Permeability assay. Serum-free DMEM was used to resuspend and adjust the cell density to $3 \times 10^{5} \mathrm{cells} / \mathrm{ml}$. The apical chamber of the Transwell was supplemented with $200 \mu \mathrm{l}$ cell suspension. DMEM medium $(600 \mathrm{ml})$ containing $20 \%$ FBS was added into
Table III. miR-141 ameliorates alcoholic hepatitis-induced pathological changes in the intestinal tissues, reflected in a lower pathological score of intestinal injury.

\begin{tabular}{lcc}
\hline Group & $\mathrm{n}$ & Pathological score \\
\hline Normal & 5 & 0 \\
Blank & 5 & $11.00 \pm 1.14^{\mathrm{a}}$ \\
NC & 5 & $11.80 \pm 1.10^{\mathrm{a}}$ \\
miR-141 mimic & 5 & $4.60 \pm 0.55^{\mathrm{a}-\mathrm{c}}$ \\
miR-141 inhibitor & 5 & $14.20 \pm 0.84^{\mathrm{a}-\mathrm{c}}$ \\
TLR4mAb & 5 & $4.80 \pm 0.45^{\mathrm{a}-\mathrm{c}}$ \\
miR-141 inhibitor + TLR4mAb & 5 & $11.00 \pm 0.71^{\mathrm{a}}$ \\
\hline
\end{tabular}

${ }^{\mathrm{a}} \mathrm{P}<0.05$ vs. the normal group; ${ }^{\mathrm{b}} \mathrm{P}<0.05$ vs. the blank group; ${ }^{\mathrm{C}}<0.05$ vs. the NC group. The measurement data were expressed as the mean \pm standard deviation and analyzed by one-way analysis of variance. $\mathrm{n}=5$. miR-141, microRNA-141; NC, negative control; TLR4mAb, Toll-like receptor 4 monoclonal antibodies.

the basolateral chamber. When the barrier model of intestinal epithelial cells in vitro was formed, $100 \mathrm{mM}$ luteolin was added to the cells in each group and cultured at $37^{\circ} \mathrm{C}$ with $5 \% \mathrm{CO}_{2}$ for $1 \mathrm{~h}$. The cells were washed by Hank's balanced salt solution (HBSS) 3 times and incubated with HBSS for $30 \mathrm{~min}$ in an incubator, the HBSS was then discarded. Then the cells in the apical chamber were incubated with $40 \mathrm{mg} / \mathrm{ml}$ fluorescein sodium at $37^{\circ} \mathrm{C}$ for $1 \mathrm{~h}$. The liquid on the basolateral chamber was collected and the fluorescence intensity was detected by multi-functional fluorescence analyzer. Fluorescein sodium transmissivity=the fluorescence amount of fluorescein sodium on the basolateral chamber/the fluorescence amount of fluorescein sodium in the apical chamber.

Statistical analysis. All data were processed by SPSS 21.0 (IBM Corp.) statistical software. All data were tested and conformed to the normal distribution and homogeneity 


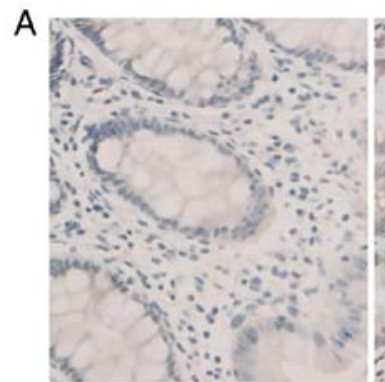

Normal

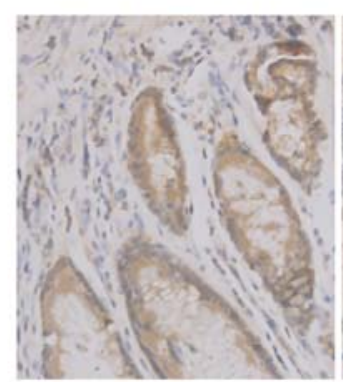

miR-141 inhibitor

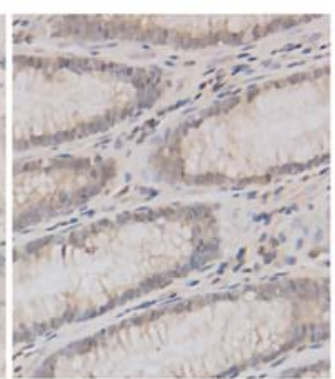

Blank

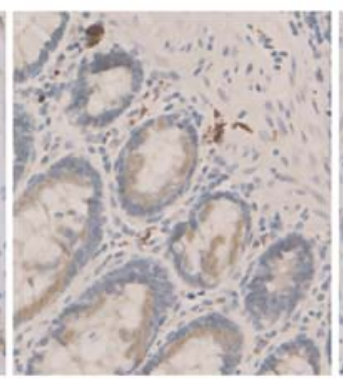

TLR4mAb

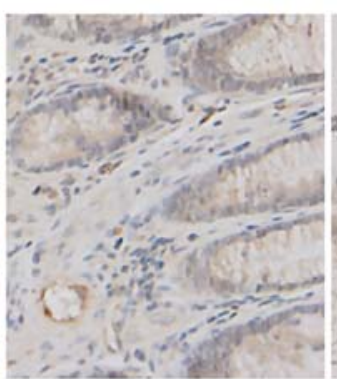

NC

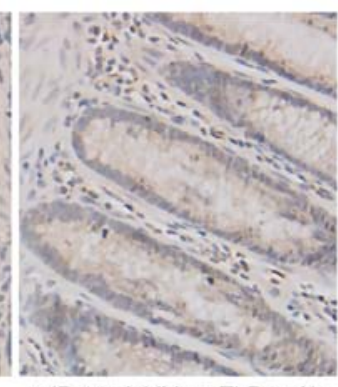

miR-141 inhibitor+TLR4mAb

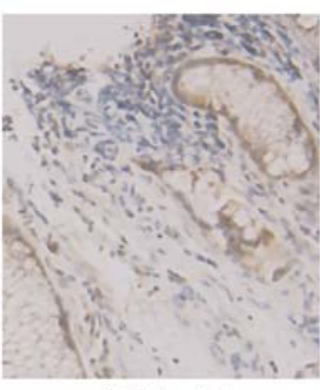

miR-141 mimic
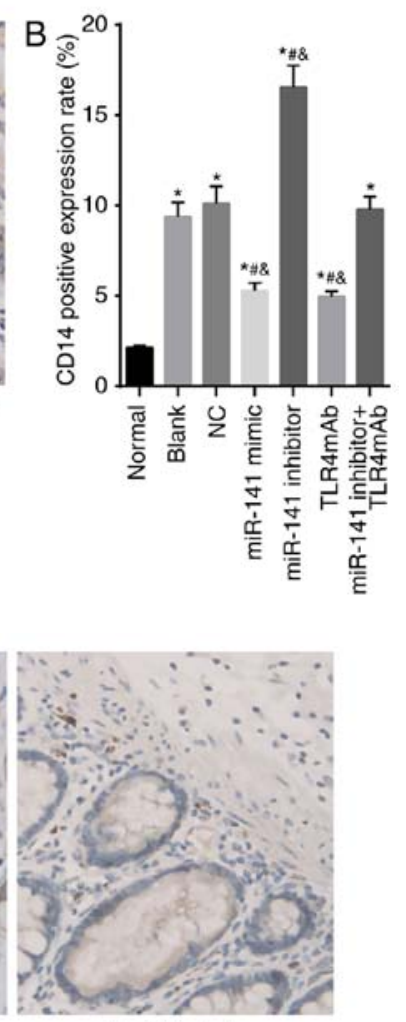

miR-141 mimic

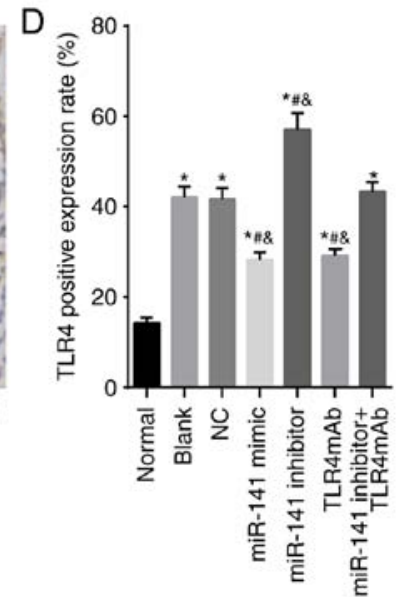

Figure 2. miR-141 decreases positive expression of TLR4 and $\mathrm{CD}_{14}$ of the intestinal tissues (x400). (A) Immunohistochemical staining of TLR4 (magnification, $\mathrm{x} 400$ ). (B) Percentage positive expression of TLR4. (C) Immunohistochemical staining of $\mathrm{CD}_{14}$ (magnification, $\mathrm{x} 400$ ). (D) Percentage positive expression of $\mathrm{CD}_{14} .{ }^{*} \mathrm{P}<0.05$ vs. the normal group; ${ }^{\#} \mathrm{P}<0.05$ vs. the blank group; ${ }^{\&} \mathrm{P}<0.05$ vs. the NC group. The measurement data were expressed as the mean \pm standard deviation, analyzed by one-way analysis of variance. $n=5$. miR-141, microRNA-141; NC, negative control; TLR4mAb, Toll-like receptor 4 monoclonal antibodies; TLR4, Toll-like receptor 4; $\mathrm{CD}_{14}$, cluster of differentiation 14 .

of variance. The measurement data were expressed as the mean \pm standard deviation. A t-test was used for comparison between two groups and one-way analysis of variance was used for comparisons among multiple groups, with Tukey's 
Table IV. miR-141 inhibits content of endotoxin, D lactic acid, DAO and ALT in the serum of alcoholic hepatitis mice.

\begin{tabular}{lccccc}
\hline Group & $\mathrm{n}$ & Serum endotoxin $(\mathrm{kEU} / \mathrm{l})$ & D lactic acid $(\mu \mathrm{g} / \mathrm{ml})$ & DAO (kU/l) & ALT $(\mathrm{U} / \mathrm{l})$ \\
\hline Normal & 5 & $0.30 \pm 0.02$ & $0.76 \pm 0.08$ & $1.90 \pm 0.20$ & $42.40 \pm 4.20$ \\
Blank & 5 & $0.71 \pm 0.06^{\mathrm{a}}$ & $2.07 \pm 0.17^{\mathrm{a}}$ & $4.50 \pm 0.40^{\mathrm{a}}$ & $354.40 \pm 32.40^{\mathrm{a}}$ \\
NC & 5 & $0.72 \pm 0.06^{\mathrm{a}}$ & $2.12 \pm 0.16^{\mathrm{a}}$ & $4.60 \pm 0.40^{\mathrm{a}}$ & $351.40 \pm 31.10^{\mathrm{a}}$ \\
miR-141 mimic & 5 & $0.47 \pm 0.04^{\mathrm{a}, \mathrm{b}}$ & $1.41 \pm 0.10^{\mathrm{a}-\mathrm{c}}$ & $3.20 \pm 0.30^{\mathrm{a}-\mathrm{c}}$ & $213.70 \pm 21.30^{\mathrm{a}-\mathrm{c}}$ \\
miR-141 inhibitor & 5 & $0.90 \pm 0.08^{\mathrm{a}, \mathrm{b}}$ & $2.79 \pm 0.18^{\mathrm{a}-\mathrm{c}}$ & $6.50 \pm 0.60^{\mathrm{a}-\mathrm{c}}$ & $466.50 \pm 45.60^{\mathrm{a}-\mathrm{c}}$ \\
TLR4mAb & 5 & $0.49 \pm 0.04^{\mathrm{a}, \mathrm{b}}$ & $1.43 \pm 0.12^{\mathrm{a}-\mathrm{c}}$ & $3.30 \pm 0.20^{\mathrm{a}-\mathrm{c}}$ & $211.70 \pm 20.20^{\mathrm{a}-\mathrm{c}}$ \\
miR-141 inhibitor + TLR4mAb & 5 & $0.73 \pm 0.06^{\mathrm{a}}$ & $2.10 \pm 0.19^{\mathrm{a}}$ & $4.60 \pm 0.50^{\mathrm{a}}$ & $359.40 \pm 29.70^{\mathrm{a}, \mathrm{c}}$ \\
\hline
\end{tabular}

${ }^{\mathrm{a}} \mathrm{P}<0.05$ vs. the normal group; ${ }^{\mathrm{b}} \mathrm{P}<0.05$ vs. the blank group; ${ }^{\mathrm{c}} \mathrm{P}<0.05$ vs. the $\mathrm{NC}$ group. The measurement data were expressed as the mean \pm standard deviation and analyzed by one-way analysis of variance. $n=5$. miR-141, microRNA-141; DAO, diamineoxidase; ALT, alanine aminotransferase; NC, negative control; TLR4mAb, Toll-like receptor 4 monoclonal antibodies.

post hoc test conducted. $\mathrm{P}<0.05$ was considered to indicate a statistically significant difference.

\section{Results}

Successful establishment of mouse model of AH. Initially, $\mathrm{H} \& \mathrm{E}$ staining was performed to observe the liver tissues in mice. The results demonstrated that compared with the normal group, the liver tissues of mice in the AH group exhibited immune cell infiltration and fatty accumulation, which was typical of $\mathrm{AH}$. The result demonstrated that the model of mice with AH was successful established (Supplementary Fig. S1).

miR-141 ameliorates AH-induced pathological alterations of the intestinal tissues. H\&E staining was also performed to observe whether miR-141 could affect AH-induced pathological changes in the intestinal tissues (Fig. 1). The structure of intestinal tissues of mice in the normal group was clear, without any abnormality. In the blank, NC and miR-141 inhibitor + TLR4mAb groups, adhesions were identified between the intestinal wall and surrounding tissues as well as hyperemia and edema in surrounding mucosa, the intestinal canal was thickened, ulcer foci was identified with thickening intestinal wall, severe mucosal edema was observed in the colon, plasma cells, lymphocytes and neutrophilic infiltration occurred in the mucosa and plasma layer, and an obvious necrosis layer and granulation tissue were identified on the ulcer surface. The intestinal tissue injury was ameliorated in the miR-141 mimic and TLR4mAb groups whereas it was aggravated in the miR-141 inhibitor group. As presented in Table III, in comparison with the normal group, all the other groups exhibited a significantly increased pathological score of intestinal tissue injury (all $\mathrm{P}<0.05)$. In comparison with the blank and NC groups, the miR-141 mimic and TLR4mAb groups exhibited a decreased pathological score while the miR-141 inhibitor group demonstrated an significantly increased pathological score $($ all $\mathrm{P}<0.05)$. There was no significant difference in terms of pathological score in the miR-141 inhibitors + TLR4mAb group $(\mathrm{P}>0.05)$. Therefore, it was suggested that miR-141 or inhibiting TLR pathway could ameliorate $\mathrm{AH}$-induced pathological changes in the intestinal tissues.
miR-141 decreases expression of TLR4 and $C D_{14}$ in the intestinal tissues. In order to evaluate the protein levels of TLR4 and $\mathrm{CD}_{14}$, immunohistochemistry was performed. As displayed in Fig. 2, TLR4 and $\mathrm{CD}_{14}$ were mainly localized in the cytoplasm. Compared with the normal group, the expression of TLR4 and $\mathrm{CD}_{14}$ was significantly increased in all the other groups (all $\mathrm{P}<0.05)$. In comparison to the blank and NC groups, the miR-141 mimic and TLR $4 m A b$ groups demonstrated significantly downregulated positive expression of TLR4 and $\mathrm{CD}_{14}$ while the miR-141 inhibitor group exhibited significantly upregulated positive expression of TLR4 and $\mathrm{CD}_{14}($ all $\mathrm{P}<0.05)$. There was no significant difference in terms of positive expression of TLR4 and $\mathrm{CD}_{14}$ between the miR-141 inhibitor + TLR $4 \mathrm{mAb}$ group and the blank and $\mathrm{NC}$ groups ( $\mathrm{P}>0.05)$. Taken together, miR-141 or TLR pathway inhibitor could decrease the expression of TLR4 and $\mathrm{CD}_{14}$ in the intestinal tissues.

miR-141 inhibits serum levels of endotoxin, D lactic acid, $D A O$ and $A L T$ in AH mice. Subsequently, the contents of endotoxin, D lactic acid, DAO and ALT in the serum of AH mice were measured. As presented in Table IV, compared with the normal group, all the other groups exhibited significantly increased levels of endotoxin, D lactic acid, DAO and ALT in serum (all $\mathrm{P}<0.05$ ), suggesting a successful establishment of model of $\mathrm{AH}$ mice. In comparison to the blank and NC groups, the miR-141 mimic and TLR4mAb groups presented significantly decreased contents of serum endotoxin, D lactic acid, DAO, and ALT while the miR-141 inhibitor group exhibited significantly increased levels of those substances (all $\mathrm{P}<0.05$ ), which indicated that overexpressed miR-141 or inhibited TLR pathway could ameliorate the intestinal injury and IETM induced by $\mathrm{AH}$. There was no significant difference in the levels of all the above indicators in the miR-141 inhibitors + TLR4mAb group compared with the blank or NC groups ( $P>0.05$, which was caused by inhibiting the miR-141 and the TLR pathway. The above results demonstrated that overexpression of miR-141 alleviated the AH-induced intestinal injury and IETM through targeting the TLR4 pathway.

miR-141 reduces $T N F-\alpha, I L-6$ and $I L-1$ contents in the intestinal tissues of AH mice. An ELISA was conducted to measure the levels of inflammatory factors TNF- $\alpha$, IL- 6 and 
Table V. miR-141 reduces content of TNF- $\alpha$, IL-6 and IL-1 in the intestinal tissues of alcoholic hepatitis mice, determined by ELISA.

\begin{tabular}{lllcc}
\hline Group & $\mathrm{n}$ & TNF- $\alpha(\mathrm{pg} / \mathrm{ml})$ & $\mathrm{IL}-6(\mathrm{pg} / \mathrm{ml})$ & $\mathrm{IL}-1 \beta(\mathrm{pg} / \mathrm{kg})$ \\
\hline Normal & 5 & $10.8 \pm 0.92$ & $47.8 \pm 3.24$ & $27.5 \pm 2.4$ \\
Blank & 5 & $26.3 \pm 2.1^{\mathrm{a}}$ & $189.5 \pm 11.26^{\mathrm{a}}$ & $128.6 \pm 13.3^{\mathrm{a}}$ \\
NC & 5 & $27.5 \pm 1.97^{\mathrm{a}}$ & $191.16 \pm 10.64^{\mathrm{a}}$ & $129.2 \pm 11.2^{\mathrm{a}}$ \\
miR-141 mimic & 5 & $19.4 \pm 1.42^{\mathrm{a}, \mathrm{b}}$ & $135.28 \pm 9.23^{\mathrm{a}-\mathrm{c}}$ & $84.5 \pm 8.4^{\mathrm{a}-\mathrm{c}}$ \\
miR-141 inhibitor & 5 & $35.2 \pm 2.81^{\mathrm{a}, \mathrm{b}}$ & $253.92 \pm 18.87^{\mathrm{a}-\mathrm{c}}$ & $162.7 \pm 15.8^{\mathrm{a}-\mathrm{c}}$ \\
TLR4mAb & 5 & $19.7 \pm 1.35^{\mathrm{a}, \mathrm{b}}$ & $138.31 \pm 8.79^{\mathrm{a}-\mathrm{c}}$ & $87.4 \pm 7.9^{\mathrm{a}-\mathrm{c}}$ \\
miR-141 inhibitor + TLR4mAb & 5 & $26.9 \pm 2.04^{\mathrm{a}}$ & $190.66 \pm 12.70^{\mathrm{a}}$ & $131.7 \pm 11.3^{\mathrm{a}}$
\end{tabular}

${ }^{\mathrm{a}} \mathrm{P}<0.05$ vs. the normal group; ${ }^{\mathrm{b}} \mathrm{P}<0.05$ vs. the blank group; ${ }^{\mathrm{c}} \mathrm{P}<0.05$ vs. the $\mathrm{NC}$ group. The measurement data were expressed as the mean \pm standard deviation and analyzed by one-way analysis of variance. $n=5$. n, number; NC, negative control; miR-141, microRNA-141; TNF- $\alpha$, tumor necrosis factor $\alpha$; IL, interleukin.
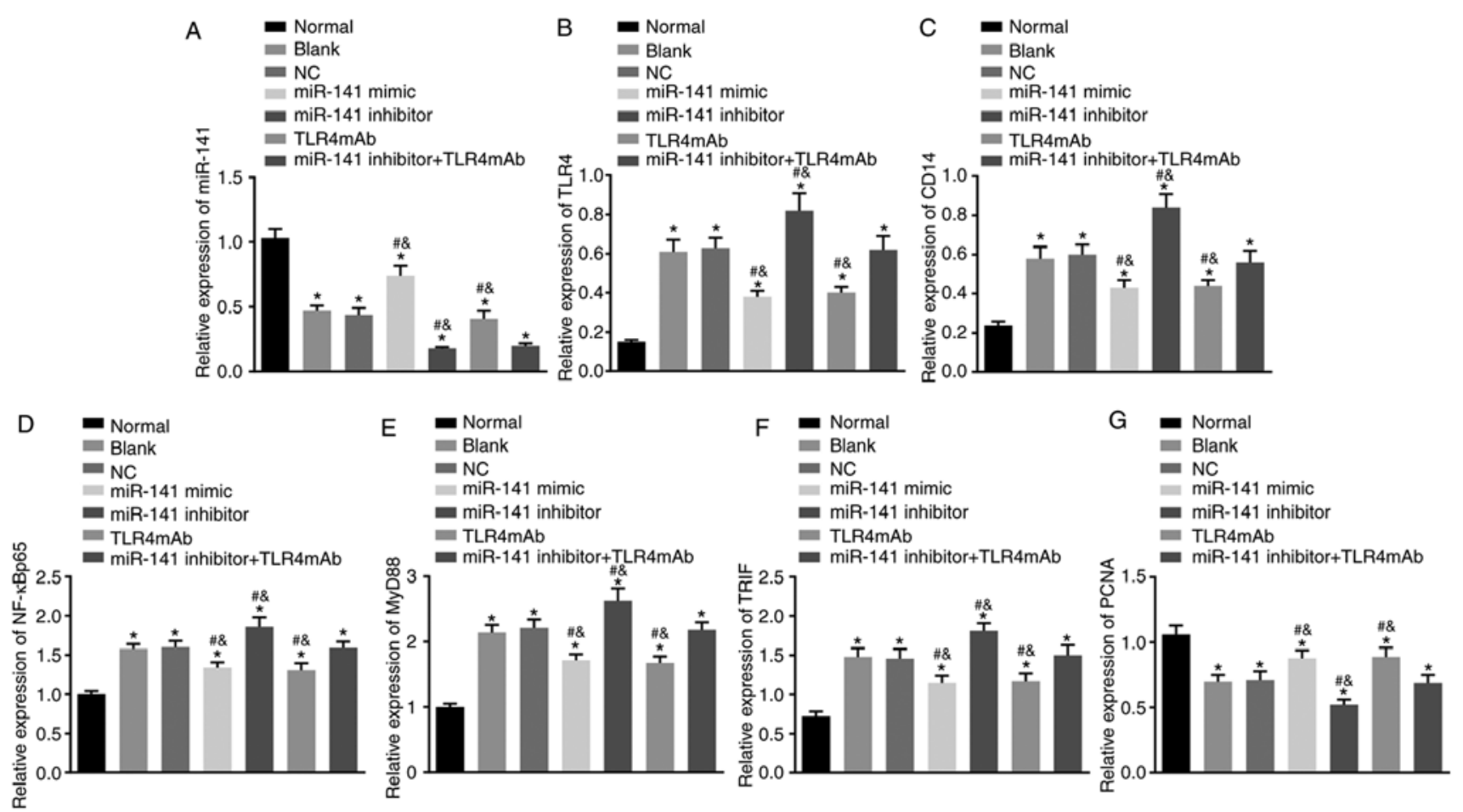

Figure 3. miR-141 downregulates the mRNA expression of TLR4, $\mathrm{CD}_{14}$, NF- $\mathrm{kBp} 65$, MyD88 and TRIF but upregulates that of PCNA in the intestinal tissues of alcoholic hepatitis mice. (A) The miR-141 expression, the mRNA expression of (B) TLR4, (C) $C_{14}$, (D) NF- $\mathrm{kBp} 65$, (E) MyD88, (F) TRIF and (G) PCNA in intestinal tissues following different treatments examined by reverse transcription quantitative polymerase chain reaction. "P<0.05 vs. the normal group;

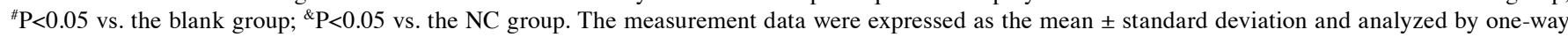
analysis of variance. $\mathrm{n}=5$. miR-141, microRNA-141; NC, negative control; TLR4mAb, Toll-like receptor 4 monoclonal antibodies; TLR4, Toll-like receptor 4;

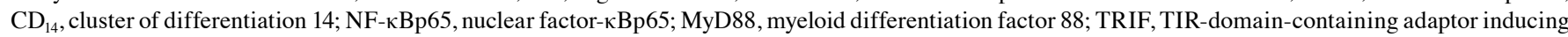
interferon- $\beta$; PCNA, proliferating cell nuclear antigen.

IL-1 in the intestinal tissues of AH mice (Table V). Compared with the normal group, all the other groups demonstrated significantly upregulated contents of TNF- $\alpha$, IL- 6 and IL-1 $\beta$ in the intestinal tissues (all $\mathrm{P}<0.05)$. In comparison to the blank and NC groups, the contents of TNF- $\alpha$, IL- 6 and IL-1 $\beta$ were notably decreased in the miR-141 mimic and TLR4mAb groups while significantly increased in the miR-141 inhibitor group (all $\mathrm{P}<0.05$ ). No significant difference was identified in the contents of TNF- $\alpha$, IL- 6 and IL- $1 \beta$ in the miR-141 inhibitor + TLR4mAb group compared with the $\mathrm{NC}$ or the blank group $(\mathrm{P}>0.05)$. The aforementioned results indicated that upregulation of miR-141 or inhibit TLR could reduce contents of TNF- $\alpha$, IL- 6 and IL-1 in the intestinal tissues of AH mice.

miR-141 downregulates the $m R N A$ level of TLR4, $C D_{I 4}$, $N F-\kappa B p 65, M y D 88$ and TRIF but upregulates the $m R N A$ level PCNA in the intestinal tissues. RT-qPCR was performed to measure the miR-141 level and mRNA levels of TLR4, $\mathrm{CD}_{14}, \mathrm{NF}-\kappa \mathrm{Bp} 65$, MyD88, TRIF and PCNA in the 
A

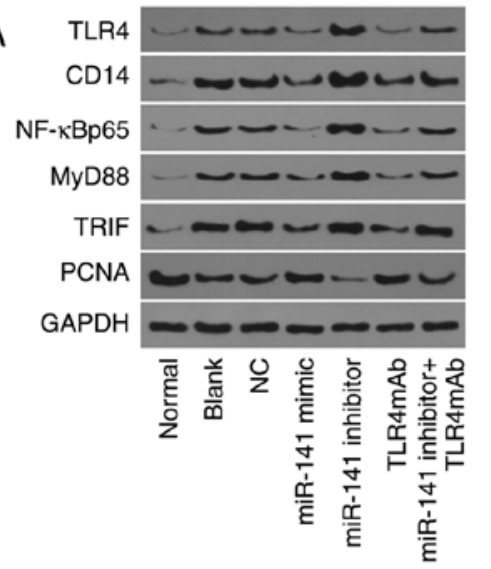

B $=$ Normal

B E Blank

NC

- miR-141 mimic

- miR-141 inhibitor

- TLR4mAb

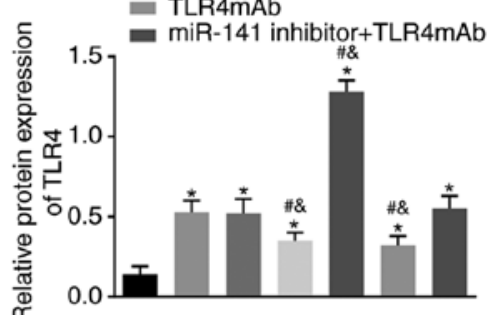

C $=$ Normal

- Blank

- NC

miR-141 mimic

- miR-141 inhibitor

- TLR4mAb

드 miR-141 inhibitor+TLR4mAb

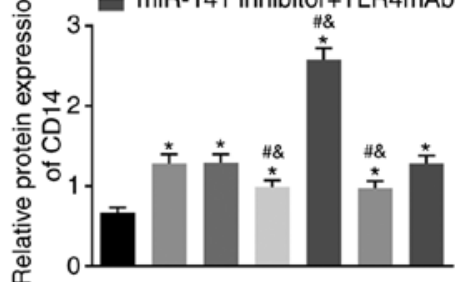

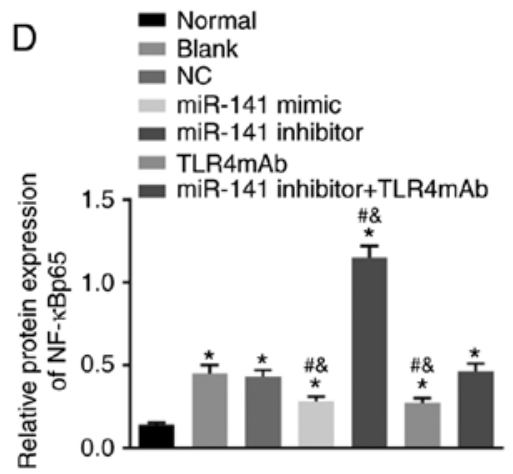
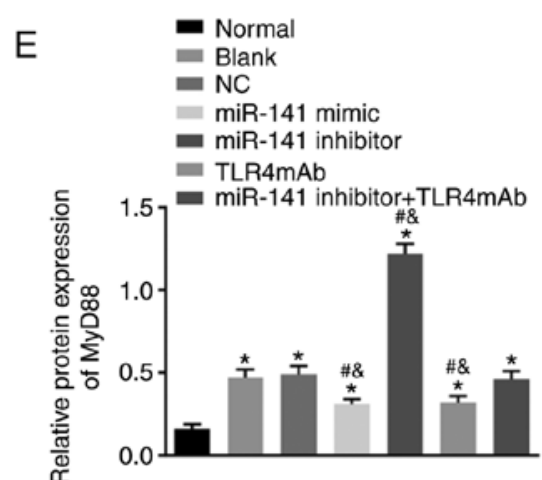

F $=$ Elank

NC

$=$ miR-141 mimic

- miR-141 inhibitor

- TLR4mAb
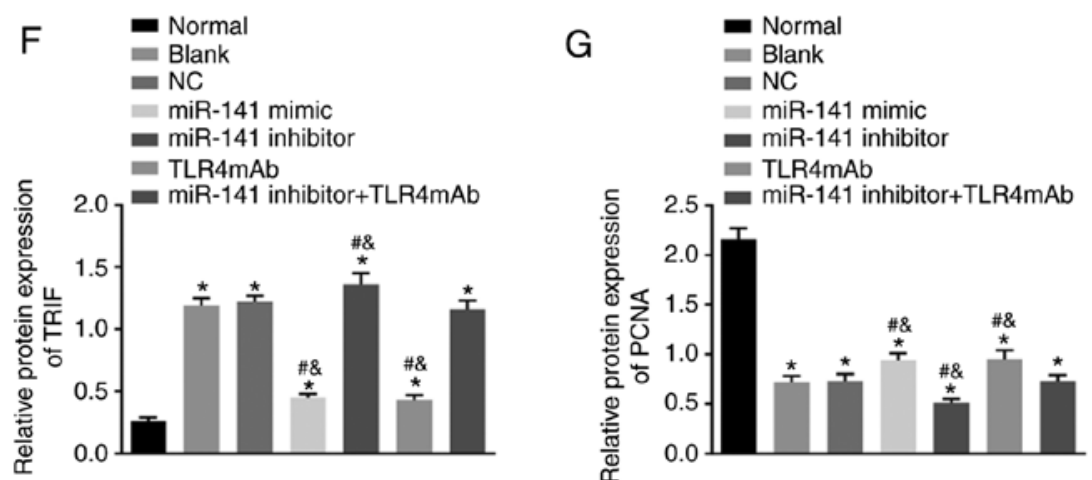

Figure 4. miR-141 inhibits the protein expression of TLR4, $\mathrm{CD}_{14}, \mathrm{NF}-\mathrm{\kappa Bp} 65$, MyD88 and TRIF but promotes the protein expression of PCNA in the intestinal tissues of AH mice. (A) The protein bands of TLR4, $\mathrm{CD}_{14}, \mathrm{NF}-\mathrm{\kappa Bp} 65$, MyD88 and TRIF and PCNA in intestinal tissues following different treatments examined western blot analysis. The protein expression of (B) TLR4, (C) $\mathrm{CD}_{14}$, (D) NF- $\mathrm{kBp} 65$, (E) MyD88, (F) TRIF and (G) PCNA in intestinal tissues following different treatments examined western blot analysis. ${ }^{*} \mathrm{P}<0.05$ vs. the normal group; ${ }^{\prime} \mathrm{P}<0.05$ vs. the blank group; ${ }^{\circledR} \mathrm{P}<0.05$ vs. the $\mathrm{NC}$ group. The measurement data were expressed as the mean \pm standard deviation and analyzed by one-way analysis of variance. $n=5$. miR-141, microRNA-141; NC, negative control; TLR4mAb,

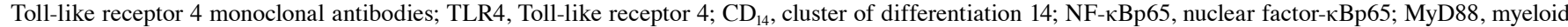
differentiation factor 88; TRIF, TIR-domain-containing adaptor inducing interferon- $\beta$; PCNA, proliferating cell nuclear antigen; AH, alcoholic hepatitis.

intestinal tissues of mice in each group. As presented in Fig. 3 , in contrast to the normal group, the levels of miR-141 and PCNA were significantly downregulated and the levels of TLR4, CD 14 , NF-кBp65, MyD88 and TRIF were significantly upregulated in the other groups (all $\mathrm{P}<0.05$ ). In comparison to the blank and $\mathrm{NC}$ groups, the miR-141 mimic and TLR $4 \mathrm{mAb}$ groups exhibited significantly upregulated expression of miR-141 and PCNA but significantly downregulated expression of TLR4, $\mathrm{CD}_{14}, \mathrm{NF}-\kappa \mathrm{Bp} 65$, MyD88 and TRIF (all $\mathrm{P}<0.05$ ), while the miR-141 inhibitor group exhibited significantly increased expression of TLR4, $\mathrm{CD}_{14}, \mathrm{NF}-\kappa \mathrm{Kp} 65, \mathrm{MyD} 88$ and TRIF but decreased expression of miR-141 and PCNA (all $\mathrm{P}<0.05$ ). The miR-141 inhibitor + TLR4mAb group revealed decreased expression of miR-141 but exhibited no obvious differences in mRNA levels of other genes compared with the blank or NC group $(\mathrm{P}>0.05)$. All the obtained data indicated that miR-141 could downregulate the mRNA levels of TLR4, $\mathrm{CD}_{14}$, NF-кBp65, MyD88 and TRIF and upregulate that of PCNA in the intestinal tissues.

miR-141 inhibits the protein levels of TLR4, $C D_{14}, N F-\kappa B p 65$, MyD88 and TRIF but increases protein level of PCNA in the intestinal tissues. Western blot analysis was conducted to determine protein levels of TLR4, $\mathrm{CD}_{14}, \mathrm{NF}-\kappa \mathrm{Bp} 65$, MyD88, TRIF and PCNA in the intestinal tissues of mice in each group. 

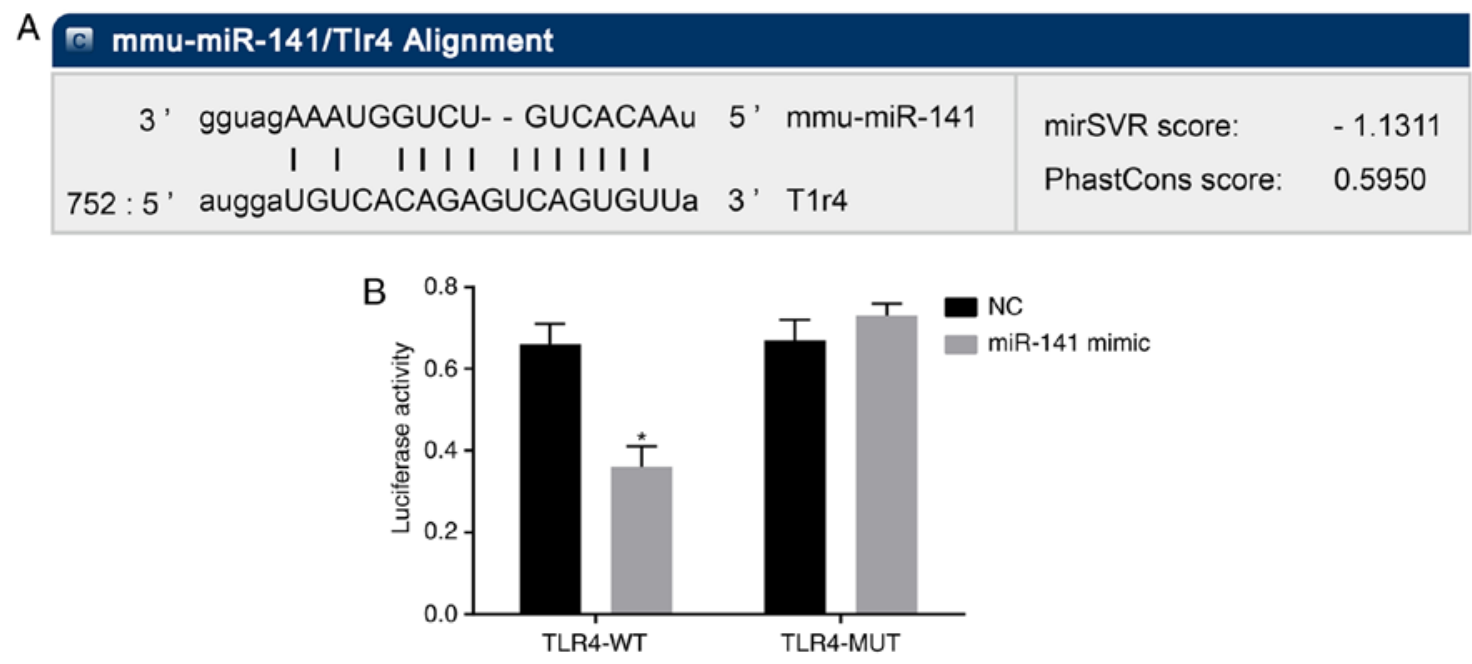

Figure 5. TLR4 is a target gene of miR-141. (A) Biological prediction of binding sites of miR-141 on TLR4. (B) Luciferase activity of TLR4-WT and TLR4-MUT in the miR-141 mimic and NC groups. ${ }^{*} \mathrm{P}<0.05$ vs. the NC group. The measurement data were expressed as the mean \pm standard deviation and comparison between two groups was analyzed by unpaired t-test. The experiment was repeated 3 times. miR-141, microRNA-141; TLR4, Toll-like receptor 4; WT, wild type; MUT, mutation; NC, negative control.

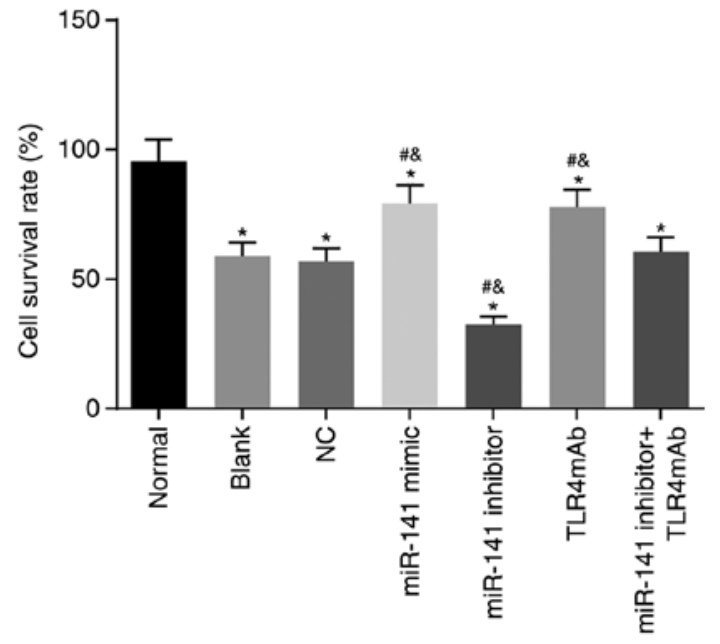

Figure 6. miR-141 promotes viability of intestinal epithelial cells. " $\mathrm{P}<0.05$ vs. the normal group; ${ }^{*} \mathrm{P}<0.05$ vs. the blank group; ${ }^{\circledR} \mathrm{P}<0.05$ vs. the $\mathrm{NC}$ group. The measurement data were expressed as the mean \pm standard deviation and analyzed by one-way analysis of variance. The experiment was repeated three times. miR-141, microRNA-141; NC, negative control; TLR4mAb, Toll-like receptor 4 monoclonal antibodies.

As presented in Fig. 4, compared with the normal group, the protein level of PCNA was decreased while the protein levels of TLR4, $\mathrm{CD}_{14}, \mathrm{NF}-\kappa \mathrm{Bp} 65, \mathrm{MyD} 88$ and TRIF were increased in all the other groups (all $\mathrm{P}<0.05)$. In comparison to the blank and NC groups, the miR-141 mimic and TLR4mAb groups presented downregulated protein levels of TLR4, $\mathrm{CD}_{14}$, NF-кBp65, MyD88 and TRIF however significantly upregulated levels of PCNA protein were identified (all $\mathrm{P}<0.05$ ). The miR-141 inhibitor group demonstrated increased expression of TLR4, $\mathrm{CD}_{14}, \mathrm{NF}-\kappa \mathrm{Bp} 65, \mathrm{MyD} 88$ and TRIF while decreased expression of PCNA (all P<0.05). The miR-141 inhibitor + TLR4mAb group exhibited no obvious differences in the protein levels of TLR4, $\mathrm{CD}_{14}, \mathrm{NF}-\kappa \mathrm{Bp} 65$, MyD88, TRIF and PCNA compared with the blank or NC group $(\mathrm{P}>0.05)$. These results suggested that miR-141 could inhibit expression of TLR4, $\mathrm{CD}_{14}, \mathrm{NF}-\kappa \mathrm{Bp} 65$, MyD88 and TRIF but promote expression of PCNA at protein levels in the intestinal tissues.

TLR4 is a target gene of $m i R-141$. Furthermore, whether miR-141 could directly regulate TLR4 was examined by target prediction program and luciferase assay. miR-141 was predicted to target TLR4 based on the biological prediction website MicroRNA.org. Moreover, the luciferase report assay results suggested that compared with the NC group, the luciferase activity of TLR4 wild-type 3'UTR was significantly inhibited by miR-141 $(\mathrm{P}<0.05)$, whereas that of the mutant 3'UTR was not affected (Fig. 5). These results indicated that miR-141 could specifically bind to 3'UTR of TLR4 and downregulate the expression of TLR4.

miR-141 promotes viability of intestinal epithelial cells. An MTT assay was applied to investigate the effect of miR-141 on viability of intestinal epithelial cells. As presented in Fig. 6, in comparison to the normal group, all the other groups exhibited significantly decreased viability of intestinal epithelial cells (all $\mathrm{P}<0.05$ ). In contrast to the blank and $\mathrm{NC}$ groups, the miR-141 mimic and TLR4mAb groups demonstrated significantly enhanced viability of intestinal epithelial cells while the miR-141 inhibitor group exhibited significantly lower viability of intestinal epithelial cells (all $\mathrm{P}<0.05$ ). No significant difference in the viability of intestinal epithelial cells was identified in the miR-141 inhibitor + TLR4mAb group compared with the blank or NC group $(\mathrm{P}<0.05)$. Therefore it was concluded that miR-141 could promote viability of intestinal epithelial cells.

miR-141 suppresses the permeability of intestinal epithelial cells. In order to examine whether miR-141 could influence the permeability of intestinal epithelial cells, permeability assay was performed. As presented in Fig. 7, the intestinal epithelial cell permeability was increased in all the other groups compared with the normal group (all $\mathrm{P}<0.05$ ). In comparison to the blank and NC groups, the cell permeability was 


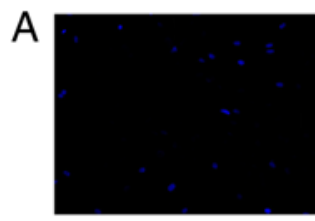

Normal

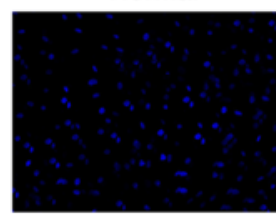

miR-141 inhibitor

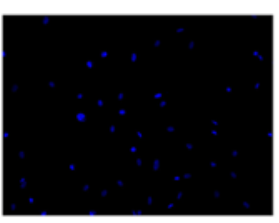

Blank

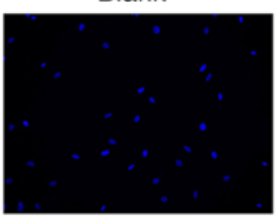

TLR4mAb

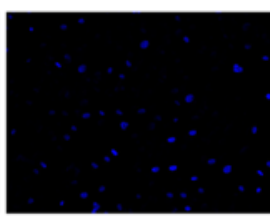

NC

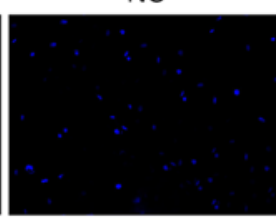

miR-141 inhibitor+

TLR4mAb

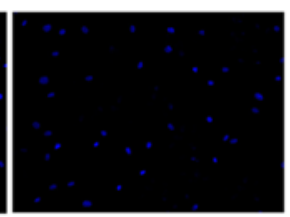

miR-141 mimic

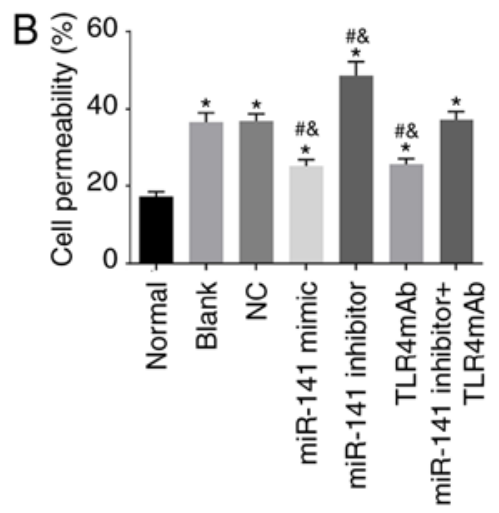

Figure 7. miR-141 suppresses the permeability of intestinal epithelial cells. (A) Fluorescein sodium staining in each group. (B) Cell permeability in the seven groups. " $\mathrm{P}<0.05$ vs. the normal group; ${ }^{*} \mathrm{P}<0.05$ vs. the blank group; ${ }^{\&} \mathrm{P}<0.05$ vs. the $\mathrm{NC}$ group. The measurement data were expressed as the mean \pm standard deviation and analyzed by one-way analysis of variance. The experiment was repeated three times. miR-141, microRNA-141; NC, negative control.

significantly decreased in the miR-141 mimic and TLR4mAb groups while significantly increased in the miR-141 inhibitor group (all $\mathrm{P}<0.05$ ). No obvious change in the cell permeability was identified in the miR-141 inhibitor + TLR4mAb group compared with the blank or normal group $(\mathrm{P}>0.05)$. The above findings revealed that miR-141 could suppress the permeability of intestinal epithelial cells.

\section{Discussion}

AH manifests the features of hepatocellular damage, fibrosis and inflammation, which has a high mortality rate without effective treatment $(24,25)$. Corticosteroids serve as a widely used treatment for $\mathrm{AH}$, but the effects differ considerably and patients with AH mainly die of infection though the infiltration of neutrophils which can cause injury to the liver (26). Previously, a study has demonstrated that miRs contribute to the pathogenesis of liver diseases and can function as diagnostic and prognostic markers as well as therapeutic targets for liver diseases (27). Therefore, the present study investigated the role of miR-141 in intestinal injury and IETM of AH and identified that miR-141 reversed intestinal injury and IETM of AH by targeting TLR4 and inhibiting the TLR signaling pathway.

Alcohol metabolism activates the innate immune cells including monocytes and macrophages in the liver, thereby promoting the progression and pathogenesis of ALD. It is reported that miR-27a is associated with the activation and polarization of alcohol-induced monocytes via the extracellular signal regulated kinase signaling pathway (28). A previous study demonstrated that miR-146b improved intestinal injury in colitis through the activation of the NF- $\kappa \mathrm{B}$ signaling pathway (29). miR-122, with various functions in hepatocytes, is also reported to be associated with acute alcohol-induced liver injury and to serve a role in regulating cholesterol metabolism (13). A previous study indicates that miR-141 exerts influence on inflammatory cell trafficking in colonic inflammation by targeting CXCL12 $\beta$ (30). miR-141 is also reported to be involved in the improvement of carrageenan-induced prostatitis through the regulation of the Kelch-like ECH-associated protein1/Nuclear factor erythroid 2-related factor 2 signaling pathway (31).
The present study revealed that upregulation of miR-141 ameliorated intestinal injury of AH by suppressing the TLR signaling pathway. It has been found that the induction of miR-155 is involved in the regulation of tenascin- $C$ in the inflammatory axis via the TLR signaling pathway (32). TLR4, a pattern recognition receptor, serves a key part in the pathogenesis of liver disease and the $\mathrm{CD}_{14} / \mathrm{TLR} 4$ receptor complex is associated with the release of inflammatory cytokines induced by lipopolysaccharide (LPS) (33). It is also demonstrated that interferon regulatory factor 3 results in liver inflammation and hepatocellular damage by mediating ischemia-reperfusion injury-induced TLR4 (34). Previous studies demonstrate that C-C motif chemokine 20 (CCL20) is a crucial mediator associated with hepatic inflammation and injury in $\mathrm{AH}$ and TLR1 in the intestinal epithelium resulted in the upregulation of CCL20 $(35,36)$. Additionally, TLR3-mediated intestinal tissue injury can be decreased by immunobiotic lactobacilli via the regulation of intraepithelial lymphocytes response (37). Another study demonstrated that that TLRs serve a protective role in necrotizing enterocolitis by producing anti-inflammatory cytokines and also have positive effects on intestinal mucosal damage by improving intestinal homeostasis (38).

In addition, the present study demonstrated that miR-141 inhibited TNF- $\alpha$, IL- 6 and IL-1 $\beta$, as well as the expression of TLR4, CD 14 , NF-кBp65, MyD88, and TRIF. TNF- $\alpha$, IL-6 and IL-1 $\beta$ are pro-inflammatory cytokines that are secreted by glial cells in the central nervous system (39). IL-1 $\beta$ is closely associated with inflammation responses and cell death in a pro-inflammatory form (40). Another study also demonstrated that the miR-141-3p mimic group exhibited decreased levels of IL-1 $\beta$, TNF- $\alpha$ and IL-6, and miR-141-3p was capable of mitigating chronic inflammatory pain by downregulating the high-mobility group box1 gene, which is consistent with the present results (41). MyD88 is rapidly produced when M1 myeloleukemic cells differentiate into macrophages, which is stimulated by IL-6 (42). TLR4 combined with LPS induces a signaling cascade via the MyD88-dependent and/or MyD88-independent pathway, which results in activating mitogen activated protein kinase 1 and nuclear factor (NF)-kB, thereby contributing to producing pro-inflammatory cytokines (43).

In addition, the present study demonstrated that miR-141 inhibited the occurrence of IETM in AH by targeting the 
TLR4 gene. It was identified that endotoxins may induce the release of pro-inflammatory cytokines since they can activate the TLR4/NF- $\kappa$ B signaling pathway (44). When epithelial mesenchymal transition (ETM) occurs, pro-inflammatory cytokines are reported to be secreted into the intestinal lumen, which promotes intestinal dysmotility and intestinal failure (45). One study revealed that miR-146a serves a significant role in endotoxin-induced cross-tolerance for monocytic cells in vitro (46). Another study also demonstrated that miR-98 remarkably reduces the triggering of endotoxin tolerance and is closely associated with the regulation of IL-10 production in endotoxin tolerance (47). Furthermore, it has been reported that LRG47 in LPS-stimulated murine macrophages inhibits the production of pro-inflammatory cytokines by downregulating TLR4 and prevents ETM by inhibiting MyD88/NF- $\mathrm{B} / \mathrm{p} 38$-induced TNF/IL-6 synthesis (48).

In conclusion, overexpression of miR-141 contributed to the inhibition of the TLR signaling pathway by targeting the TLR4 gene, thereby rescuing intestinal injury and IETM of $\mathrm{AH}$, which will provide a novel basis for the treatment of intestinal injury and IETM in AH.

\section{Acknowledgements}

Not applicable.

\section{Funding}

The present study was funded by the Huai'an Natural Science Foundation (grant no. HAB201722) and Nanjing Medical University Natural Science Foundation (grant no. 2016NJMU137).

\section{Availability of data and materials}

The datasets used and analyzed during the current study are available from the corresponding author on reasonable request.

\section{Authors' contributions}

WQ and YL designed the study. WQ, XL, and YP collated the data, designed and developed the database, carried out data analyses and produced the initial draft of the manuscript. WQ and YL contributed to drafting the manuscript. All authors participated in the revised manuscript and have read and approved the final submitted manuscript.

\section{Ethics approval and consent to participate}

All animal experiments involved in the present study were in line with the principles of the approval of the clinical ethical committee of the Affiliated Huai'an Hospital of Xuzhou Medical University. Significant efforts were made in order to minimize the number of animals used as well as their respective suffering.

\section{Patient consent for publication}

Not applicable.

\section{Competing interests}

The authors declare that they have no competing interests.

\section{References}

1. Damgaard Sandahl T: Alcoholic hepatitis. Dan Med J 61: B4755, 2014.

2. Kendrick SF, O'Boyle G, Mann J, Zeybel M, Palmer J, Jones DE and Day CP: Acetate, the key modulator of inflammatory responses in acute alcoholic hepatitis. Hepatology 51: 1988-1997, 2010.

3. Chayanupatkul M and Liangpunsakul S: Alcoholic hepatitis: A comprehensive review of pathogenesis and treatment. World J Gastroenterol 20: 6279-6286, 2014.

4. Singal AK, Kamath PS, Gores GJ and Shah VH: Alcoholic hepatitis: Current challenges and future directions. Clin Gastroenterol Hepatol 12: 555-564; quiz e31-e32, 2014.

5. Raff E and Singal AK: Optimal management of alcoholic hepatitis. Minerva Gastroenterol Dietol 60: 25-38, 2014.

6. Torok NJ: Update on alcoholic hepatitis. Biomolecules 5: 2978-2986, 2015.

7. Yan AW and Schnabl B: Bacterial translocation and changes in the intestinal microbiome associated with alcoholic liver disease. World J Hepatol 4: 110-118, 2012.

8. Schnabl B and Brenner DA: Interactions between the intestinal microbiome and liver diseases. Gastroenterology 146: 1513-1524, 2014.

9. Rao R: Endotoxemia and gut barrier dysfunction in alcoholic liver disease. Hepatology 50: 638-644, 2009.

10. McDaniel K, Herrera L, Zhou T, Francis H, Han Y, Levine P, Lin E, Glaser S, Alpini G and Meng F: The functional role of microRNAs in alcoholic liver injury. J Cell Mol Med 18: 197-207, 2014.

11. Szabo G and Satishchandran A: MicroRNAs in alcoholic liver disease. Semin Liver Dis 35: 36-42, 2015.

12. Blaya D, Coll M, Rodrigo-Torres D, Vila-Casadesús M, Altamirano J, Llopis M, Graupera I, Perea L, Aguilar-Bravo B, Diaz A, et al: Integrative microRNA profiling in alcoholic hepatitis reveals a role for microRNA-182 in liver injury and inflammation. Gut 65: 1535-1545, 2016.

13. Bala S, Petrasek J, Mundkur S, Catalano D, Levin I, Ward J, Alao H, Kodys K and Szabo G: Circulating microRNAs in exosomes indicate hepatocyte injury and inflammation in alcoholic, drug-induced, and inflammatory liver diseases. Hepatology 56: 1946-1957, 2012.

14. Lucas K and Maes M: Role of the Toll Like receptor (TLR) radical cycle in chronic inflammation: Possible treatments targeting the TLR4 pathway. Mol Neurobiol 48: 190-204, 2013.

15. Zhou X, Ye F, Yin C, Zhuang Y, Yue G and Zhang G: The interaction between MiR-141 and lncRNA-H19 in regulating cell proliferation and migration in gastric cancer. Cell Physiol Biochem 36: 1440-1452, 2015.

16. Xue J, Niu YF, Huang J, Peng G, Wang LX, Yang YH and Li YQ: miR-141 suppresses the growth and metastasis of HCC cells by targeting E2F3. Tumour Biol 35: 12103-12107, 2014.

17. Huang XY, Huang ZL, Xu YH, Zheng Q, Chen Z, Song W, Zhou J, Tang ZY and Huang XY: Comprehensive circular RNA profiling reveals the regulatory role of the circRNA-100338/miR-141-3p pathway in hepatitis B-related hepatocellular carcinoma. Sci Rep 7: 5428, 2017.

18. Cai M, Chen S and Hu W: MicroRNA-141 is involved in ulcerative colitis pathogenesis via aiming at CXCL5. J Interferon Cytokine Res 37: 415-420, 2017.

19. Lowe PP, Gyongyosi B, Satishchandran A, Iracheta-Vellve A, Ambade A, Kodys K, Catalano D, Ward DV and Szabo G: Alcohol-related changes in the intestinal microbiome influence neutrophil infiltration, inflammation and steatosis in early alcoholic hepatitis in mice. PLoS One 12: e0174544, 2017.

20. Geboes K, Riddell R, Ost A, Jensfelt B, Persson T and Löfberg R: A reproducible grading scale for histological assessment of inflammation in ulcerative colitis. Gut 47: 404-409, 2000.

21. Wang X, Sun L, Wang X, Kang H, Ma X, Wang M, Lin S, Liu M, Dai C and Dai Z: Acidified bile acids enhance tumor progression and telomerase activity of gastric cancer in mice dependent on c-Myc expression. Cancer Med 6: 788-797, 2017. 
22. Li X, Li D, Zhuang Y, Shi Q, Wei W and Ju X: Overexpression of miR-708 and its targets in the childhood common precursor B-cell ALL. Pediatr Blood Cancer 60: 2060-2067, 2013.

23. Ayuk SM, Abrahamse H and Houreld NN: The role of photobiomodulation on gene expression of cell adhesion molecules in diabetic wounded fibroblasts in vitro. J Photochem Photobiol B 161: 368-374, 2016.

24. Dominguez M, Miquel R, Colmenero J, Moreno $M$, García-Pagán JC, Bosch J, Arroyo V, Ginès P, Caballeria J and Bataller R: Hepatic expression of CXC chemokines predicts portal hypertension and survival in patients with alcoholic hepatitis. Gastroenterology 136: 1639-1650, 2009.

25. Boetticher NC, Peine CJ, Kwo P, Abrams GA, Patel T, Aqel B, Boardman L, Gores GJ, Harmsen WS, McClain CJ, et al: A randomized, double-blinded, placebo-controlled multicenter trial of etanercept in the treatment of alcoholic hepatitis. Gastroenterology 135: 1953-1960, 2008.

26. Mookerjee RP, Stadlbauer V, Lidder S, Wright GA, Hodges SJ, Davies NA and Jalan R: Neutrophil dysfunction in alcoholic hepatitis superimposed on cirrhosis is reversible and predicts the outcome. Hepatology 46: 831-840, 2007.

27. Wang XW, Heegaard NH and Orum H: MicroRNAs in liver disease. Gastroenterology 142: 1431-1443, 2012.

28. Saha B, Bruneau JC, Kodys K and Szabo G: Alcohol-induced miR-27a regulates differentiation and M2 macrophage polarization of normal human monocytes. J Immunol 194: 3079-3087, 2015.

29. Nata T, Fujiya M, Ueno N, Moriichi K, Konishi H, Tanabe H, Ohtake T, Ikuta K and Kohgo Y: MicroRNA-146b improves intestinal injury in mouse colitis by activating nuclear factor- $\kappa \mathrm{B}$ and improving epithelial barrier function. J Gene Med 15 249-260, 2013

30. Huang Z, Shi T, Zhou Q, Shi S, Zhao R, Shi H, Dong L, Zhang C, Zeng K, Chen J and Zhang J: miR-141 Regulates colonic leukocytic trafficking by targeting CXCL12 $\beta$ during murine colitis and human Crohn's disease. Gut 63: 1247-1257, 2014.

31. Wang LL, Huang YH, Yan CY, Wei XD, Hou JQ, Pu JX and Lv JX: N-acetylcysteine ameliorates prostatitis via miR-141 regulating keap1/Nrf2 signaling. Inflammation 39: 938-947, 2016.

32. Piccinini AM and Midwood KS: Endogenous control of immunity against infection: Tenascin-C regulates TLR4-mediated inflammation via microRNA-155. Cell Rep 2: 914-926, 2012.

33. Von Hahn T, Halangk J, Witt H, Neumann K, Müller T, Puhl G, Neuhaus P, Nickel R, Beuers U, Wiedenmann B and Berg T: Relevance of endotoxin receptor CD14 and TLR4 gene variants in chronic liver disease. Scand J Gastroenterol 43: 584-592, 2008.

34. Zhai Y, Shen XD, O'Connell R, Gao F, Lassman C, Busuttil RW, Cheng G and Kupiec-Weglinski JW: Cutting edge: TLR4 activation mediates liver ischemia/reperfusion inflammatory response via IFN regulatory factor 3-dependent MyD88-independent pathway. J Immunol 173: 7115-7119, 2004.

35. Affò S, Morales-Ibanez O, Rodrigo-Torres D, Altamirano J, Blaya D, Dapito DH, Millán C, Coll M, Caviglia JM, Arroyo V, et al: CCL20 mediates lipopolysaccharide induced liver injury and is a potential driver of inflammation and fibrosis in alcoholic hepatitis. Gut 63: 1782-1792, 2014.
36. Sugiura Y, Kamdar K, Khakpour S, Young G, Karpus WJ and DePaolo RW: TLR1-induced chemokine production is critical for mucosal immunity against Yersinia enterocolitica. Mucosal Immunol 6: 1101-1109, 2013.

37. Tada A, Zelaya H, Clua P, Salva S, Alvarez S, Kitazawa H and Villena J: Immunobiotic Lactobacillus strains reduce small intestinal injury induced by intraepithelial lymphocytes after Toll-like receptor 3 activation. Inflamm Res 65: 771-783, 2016.

38. Tatum PM Jr, Harmon CM, Lorenz RG and Dimmitt RA: Toll-like receptor 4 is protective against neonatal murine ischemia-reperfusion intestinal injury. J Pediatr Surg 45: 1246-1255, 2010.

39. Choi BM, Lee SH, An SM, Park DY, Lee GW and Noh GJ: The time-course and RNA interference of TNF- $\alpha$, IL-6, and IL-1 $\beta$ expression on neuropathic pain induced by L5 spinal nerve transection in rats. Korean J Anesthesiol 68: 159-169, 2015.

40. Peng Y, French BA, Tillman B, Morgan TR and French SW: The inflammasome in alcoholic hepatitis: Its relationship with Mallory-Denk body formation. Exp Mol Pathol 97: 305-313, 2014.

41. Shen WS, Xu XQ, Zhai NN, Zhou ZS, Shao J and Yu YH: Potential mechanisms of microRNA-141-3p to alleviate chronic inflammatory pain by downregulation of downstream target gene HMGB1: In vitro and in vivo studies. Gene Ther 24: 353-360, 2017.

42. Akira S and Takeda K: Toll-like receptor signalling. Nat Rev Immunol 4: 499-511, 2004.

43. Chen Q, Wang H, Liu Y, Song Y, Lai L, Han Q, Cao X and Wang Q: Inducible microRNA-223 down-regulation promotes TLR-triggered IL- 6 and IL- $1 \beta$ production in macrophages by targeting STAT3. PLoS One 7: e42971, 2012.

44. Grimaldi D, Guivarch E, Neveux N, Fichet J, Pène F, Marx JS, Chiche JD, Cynober L, Mira JP and Cariou A: Markers of intestinal injury are associated with endotoxemia in successfully resuscitated patients. Resuscitation 84: 60-65, 2013.

45. Sonnier DI, Bailey SR, Schuster RM, Gangidine MM, Lentsch $\mathrm{AB}$ and Pritts TA: Proinflammatory chemokines in the intestinal lumen contribute to intestinal dysfunction during endotoxemia. Shock 37: 63-69, 2012.

46. Nahid MA, Satoh M and Chan EK: Mechanistic role of microRNA-146a in endotoxin-induced differential cross-regulation of TLR signaling. J Immunol 186: 1723-1734, 2011.

47. Liu Y, Chen Q, Song Y, Lai L, Wang J, Yu H, Cao X and Wang Q: MicroRNA-98 negatively regulates IL-10 production and endotoxin tolerance in macrophages after LPS stimulation. FEBS Lett 585: 1963-1968, 2011.

48. Bafica A, Feng CG, Santiago HC, Aliberti J, Cheever A, Thomas KE, Taylor GA, Vogel SN and Sher A: The IFN-inducible GTPase LRG47 (Irgm1) negatively regulates TLR4-triggered proinflammatory cytokine production and prevents endotoxemia. J Immunol 179: 5514-5522, 2007.

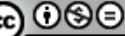

This work is licensed under a Creative Commons Attribution-NonCommercial-NoDerivatives 4.0 International (CC BY-NC-ND 4.0) License. 